Summer 2005

\title{
Good Administration and Administrative Procedures
}

Juli Ponce

University of Barcelona

Follow this and additional works at: https://www.repository.law.indiana.edu/ijgls

Part of the Administrative Law Commons, and the International Law Commons

\section{Recommended Citation}

Ponce, Juli (2005) "Good Administration and Administrative Procedures," Indiana Journal of Global Legal Studies: Vol. 12 : Iss. 2 , Article 10.

Available at: https://www.repository.law.indiana.edu/ijgls/vol12/iss2/10

This Symposium is brought to you for free and open access by the Law School Journals at Digital Repository @ Maurer Law. It has been accepted for inclusion in Indiana Journal of Global Legal Studies by an authorized editor of Digital Repository @ Maurer Law. For more information, please contact rvaughan@indiana.edu.

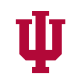

JEROME HALL LAW LIBRARY

$$
\text { INDIANA UNIVERSITY }
$$

Maurer School of Law
Blooming ton 


\title{
Good Administration and Administrative Procedures
}

\author{
Dr. Juli Ponce*
}

This article examines the relationship between administrative procedures, the duty of giving reasons, and the citizens' participation in relation to the quality of the administrative behavior. I will take into account some national experiences and will reflect about some crucial issues connected with fundamental rights and administrative procedures in the European Union (EU). The U.S. model will also be considered.'

This study focuses on adjudicative procedures. I will not analyze rulemaking procedures, but a number of brief considerations about them will be included in the final part.

The three fundamental questions are:

(1) What purpose do administrative procedures serve? That is, why do must public authorities follow an administrative procedure when making a public decision?

(2) Is it a good or bad idea to regulate administrative procedure? If good, how best to regulate it?

(3) Who should re oulate administrative procedures?

The article will begin by analyzing the functions of administrative procedures as legal institutions. I will distinguish the instrumental functions from the noninstrumental, paying special attention to the relationship between good administration and its procedural aspects. Secondly, I will consider whether it is a good idea to codify administrative procedures, and discuss arguments in favor of

\footnotetext{
*Professor Titular de Derecho Administrativo, University of Barcelona, Spain.

1. The article presented here is partly based on several previously published studies. See Jun Ponce, Deber de Buena Administración y Derecho al Procedimiento Administrativo Debido: Las Bases Constitucionales del Procedimiento Administrativo y Del Ejercicio de la Discrecionalidad (2001); Juli Ponce, Good Administration and European Public Law: The Fight for Quality in the Field of Administrative Decisions, 14 Eur. Rev. Pub. L. 1503 (2002) [hereinafter Good Administration and European Public Law]; Juli Ponce, La calidad en el desarrollo de la discrecionalidad reglamentaria: teorías sobre la regulación y adopción de buenas decisiones normativas por los Gobiernos y las Administraciones, 162 Revista de Administración Pública 89 (2003) [hereinafter La calidad en el desarrollo de la discrecionalidad reglamentaria].
} 
and against codification. Accepting that codification could be a good idea, I will then examine the different possible ways of codifying procedures, analyzing the first European attempt to regulate the administrative procedures that have taken shape in the European Code of Good Administrative Behaviour. ${ }^{2}$ Later, I will examine the subjects given responsibility for codifying administrative procedures. Thus, I will consider the role of the Constitution, the Parliament, and the executive branch, as well as case law intervention. I will conclude with some brief reflections about rulemaking.

I will adopt an international and comparative approach, analyzing European national administrative laws, EU law, and U.S. law. The goal is to show that although there are differences between those legal systems, there is a certain degree of convergence in relation to problems and solutions. This is not surprising, given our increasingly globalized world.

\section{What are the Functions and Rationales of Administrative Procedure?}

Differences may be distinguished between noninstrumental and instrumental functions:

a. Noninstrumental functions: administrative procedure plays a role by itself without being linked to the final decision that is its output. Among these functions can be highlighted at least the following:

(1) protection of personal dignity (a dignified approach linked to Kant's ideas); $;^{3}$

(2) promotion of citizens' participation (sometimes associated with deliberative democracy following Habermas' ideas, for example); ${ }^{4}$

(3) enhancing transparency and accountability; ${ }^{5}$ and

2. European Commission, Code of Good Adminstrative Behaviour [hereinafter European Code of Good Administrative Behaviour] (200I), available at http:/www.euro-ombudsman. eu.int/code/pdf/en/code_en.pdf (last visited Apr. 3, 2005).

3. P.P. Craig, Procedures and Administrative Decision-making: A Common Law Perspective, 5 Eur. Rev. Pub. L. 55 (1993).

4. Rafael Rubio, Los Grupos de Presión 100 (2003).

5. Denis Galligan, Principal Institutions and Mechanisms of Accountability, in Comprenensive Legal and Judicial Development 31 (Rudolf V. Van Puymbroeck ed., 2001); Carol Harlow, AcCOUNTABility in the European Union 159 (2002). 
(4) improvement of legitimacy. Administrative procedures compensate for the lack of formal rationality owing to the lack of legal predetermination in the case of existing discretionary areas of judgment, offering an extra legitimacy based on more democracy and better quality of the outputs. ${ }^{6}$

b. Instrumental functions: from this perspective, administrative procedure guarantees the correctness of the substantive outcome. Administrative procedure is useful for:

(1) the protection of rights and interests (the procedure then acting as a legal "shield") and

(2) the promotion of good administration and, consequently, the quality of final decisions, especially if discretionary powers exist. ${ }^{\text {? }}$

In order to develop this second role of administrative procedures in relation to outcome-that is, the promotion of good administration-it is first necessary to understand the meaning of discretionary powers.

The European concept of discretionary powers entails two common notions: choice and general interest. Academic writers agree that discretion means that public administration is empowered by law to choose from among several legal possibilities, taking into account nonjuridical criteria. This choice implies balancing public and private interests by using extralegal values to define a general interest that is not established by statutes.

A particular recommendation by the Committee of Ministers is of interest in the field of European Community (EC) law; in its appendix, this recommendation defines "discretionary power" as a "power which leaves an administrative authority some degree of latitude as regards the decision to be taken, enabling it to choose from among several legally admissible decisions the one which it finds to be the most appropriate."

6. Niklas Luhmann, Legitima Durch Verfahren (1969).

7. Lord Millet, The Right to Good Administration in European Law, 47 Puв. L. 309, 310 (2002), (explaining that "[b]y good administration is meant good administrative procedures"). I agree with this statement but must add a nuance: good administration means good administrative procedures and good reasons to back the final decision, as we will see shortly.

8. Recommendation of the Comm. of Ministers No. $R(80) 2$ Concerning the Exercise of Discretionary Powers by Administrative Authorities, 316th Mtg. (1980) (adopted by the Committee of Ministers on March 11, 1980 at the 316th meeting of the Ministers' deputies) [hereinafter Recommendation of the Comm. of Ministers]. 
The core of discretion, that is, the choice between alternatives, is something odd in traditional administrative law, which does not deal with it, except for delimiting boundaries for discretion that cannot be crossed. The choice itself is considered a matter of politics, not a legal issue. In the traditional paradigm, administrative law provides, above all, a defense for individuals, a shield against arbitrary decisions.

From that point of view, where statute ends, tyranny begins--and the only effective protection against tyranny is judicial review. Therefore, traditional administrative law is not especially interested in good administrative decisions but in the judicial review of illegal decisions, to protect citizens against public arbitrariness. This is a negative approach in the sense that it is an approach against arbitrariness that does not favor good administration, and it is possible to link this point of view with Harlow and Rawling's metaphor of red-light theorists. ${ }^{9}$ This approach has been common in Spain for a long time, as well as in other European countries, as detailed by Cassese's explanation of the principle of legality as a "fetish." 10

But a new viewpoint is growing all around Europe. This new approach is concerned with the quality of decisions, a relatively new paradigm for us, but well established in the United States. The discretionary choice itself is relevant for administrative law, because it is concerned with good decisions and with good administration. It is important that public administration makes both legal and correct decisions, with proper reasoning to back them. This is important because people demand that such good decisions be made and they want to participate in decisions that affect them most, such as where a highway should be constructed or where a nuclear plant should be built.

As Braibant has graphically pointed out, "Even when public authorities are allowed to do what they want, they cannot do whatever." "That is, the proper use of discretionary powers matters to public law. And the proper use of discretionary power is defined by the idea of good administration. This concept cannot be a pass par tout, but has to have its own meaning as a legal technique.

9. See Carol Harlow \& Richard Rawlings, Law and Administration 29 (1997), as well as commentary on this book in Michael Taggart, Reinvented Government, Traffic Lights and the Convergence of Public and Private Law-Review of Harlow and Rawlings: Law and Administration, 44 Pub. L. 124 (1999).

10. Sabino Cassese, Las Bases del Derecho Administrativo (1994).

11. Author's translation. See Sieur Lambert, Braibant's Conclusions “CE,” 27 L'Actualiré juridique: Droit administratif 53 (1971). 
But, what does good administration mean? As a first idea, we can say that good administration is the opposite of maladministration. But then what does maladministration mean?

We can refer to the British system to try to define maladministration. The British Ombudsman has been fighting against it since the 1960s. There is no definition of maladministration in the British legal system, although the so-called Crossman's catalogue ${ }^{12}$ is frequently used, which defines maladministration as "bias, neglect, inattention, delay, incompetence, ineptitude, perversity, turpitude, arbitrariness and so on." 13 The Ombudsman has focused his activity on guaranteeing that public administration follows good procedures before exercising its powers. As Greenwood and Wilson point out, "[e]ssentially, maladministration concerns defects in administrative procedures, not the merits or substance of decisions." 14

Regarding the European Ombudsman, the Treaty on the European Union created this figure and defined his responsibility as fighting against maladministration of Community institutions, except the European Court of Justice when it is carrying out its judicial functions. ${ }^{15}$

But the question remains. What is maladministration? Obviously, as I introduced above, it is the opposite of good administration. But attempting to define it is not so easy. As the European Ombudsman, Jacob Söderman, who was appointed by the European Parliament in 1995, highlighted: it is not a good idea to define maladministration because one needs flexibility to carry out one's function properly. ${ }^{16}$ We could jokingly paraphrase U.S. Supreme Court Justice Potter Stewart, "we know maladministration when we see it," which was used to describe the definition of obscenity. But there are a number of clues that can help define maladministration. The European Ombudsman established that "maladministration occurs when a public body fails to act in accordance with a rule

12. So named because it was the list of traits that maladministration might have, given by the then-Lord President of the Council in the debates on the Parliamentary Commissioner Bill in 1967.

13. See, e.g., Parliamentary and Health Service Ombudsman, Sir William Reid's Definition of Maladministration, at http://www.ombudsman.org.uk/foi/ps2b_iv_maladmin.htm (last visited Apr. 2, 2005).

14. John R. Greenwood \& David J. Wilson, Public Administration in Britain Today 313 (1989).

15. Treaty Establishing the European Community, art. 195, 2002 O.J. (C 325) 120, available at http://europa.eu.int/eur-lex/lex/en/treaties/dav/12002E/htm/12002E.html (last visited Apr. 2, 2005).

16. See J. Söderman, El Derecho Fundamental a Una Buena Administración, 214 G.J. 8 (2001). 
or principle which is binding upon it." 17 If we wish to be more precise, we can analyze some European legal systems, such as the Italian or the Spanish systems, and their efforts to define and develop principles of good administration.

The 1947 Italian Constitution establishes ${ }^{18}$ that Italian agencies must be organized so as to achieve administrative impartiality and buon andamento. The last words have been considered by many Italian scholars to be a duty of good administration (buona amministrazione). The Corte Costituzionale has declared that this duty obliges legislators to design proper administrative structures and procedures to carry out administrative functions. On the other hand, the principle imposes on public administration the duty of making sound decisions by gathering necessary information and balancing the relevant factors in each case before deciding. ${ }^{19}$

The current Spanish Constitution of 1978 is especially interesting. It provides in Articles 31 and 103 that public administration must act with objectivity and impartiality, in accordance with the principles of effective action, efficiency, economy and coordination ${ }^{20}$ it also establishes a prohibition of arbitrariness. ${ }^{21}$

Although it is not still an established paradigm, scholars and some case law use the words buena administración (good administration) in relation to the duty of achieving good administrative decisions. On the other hand, in the last few years, scholars have emphasized the need for statements of reasons to guarantee a good use of discretionary powers.

Based on these issues, we have had the opportunity to study in depth the constitutional principles of rationality (connected with the prohibition of arbitrariness mentioned earlier), objectivity and impartiality, effective action, efficiency, economy, and coordination, by using a comparative method and taking into account several European legal systems. Because it is not the aim of this article to repeat what has been written before, ${ }^{22}$ I simply will outline the Spanish constitutional duty of good administration.

All the principles previously mentioned may be included in a more general concept, the duty of good administration, established initially by Spanish legisla-

17. The European Ombudsman, Annual Report for 1997, at 23.

18. La Costituzione della Repubblica Italiana of 1947 [Constitution] art. 97 (It.).

19. See, e.g., Guido Falzone, Il dovere di buona amministrazione (1953).

20. Constitución Española de 1978 [Constitution] pt. I, ch. 2, div. 2, § 31; pt. IV, § 103 (Sp.).

21. Id. $\S 9, \mathrm{cl} .3$.

22. See Ponce, supra note 1; Good Administration and European Public Law, supra note 1; La calidad en el desarrollo de la discrecionalidad reglamentaria, supra note 1. 
tion regarding contracts, and later by case law. But so far this legal concept has suffered from a lack of consistent theoretical construction. Therefore, it is necessary to define the meaning of such a duty and its legal consequences in connection with the key role of administrative procedure.

The Spanish Constitution of 1978 contains a series of principles referring to the development of the activity of service to general interests. ${ }^{23}$ This is a group of principles of buena administracion - to use the traditional expression from Spanish legislation that refers to contracts - that guides the way of conducting administrative activity and, therefore, indirectly, though undoubtedly, conditions the content of its result.

Worthy of mention are also the British efforts to build several principles of good administration. The Committee of the Justice-All Souls, a nongovernmental institution, published a report that contained a draft of principles of good administration. ${ }^{24}$ The report recommended that Parliament enact a statement of principles of good administration in order to guide administrative activity in the United Kingdom. Seventeen years later, the same institution published another report ${ }^{25}$ that included a chapter on principles of good administration. ${ }^{26}$ The report underlines that "[g]ood administration is more to be desired than remedies for bad administration" 27 and that "[a]s prevention is better than cure, so good administration is better than remedies for bad administration." 28

23. Constitución Española de 1978 § 9, cl. 3; pt. I, ch. 2, div. 2, § 31, cl. 2; pt. IV, § 103, cl. 1 (Sp.).

24. See Committee of Justice, Keith Goodfellow, Chairman, Administration Under Law (1971). Principle number 1 reads:

Before making any decision, an authority shall take all reasonable steps to ensure that all persons who will be particularly and materially affected by such decision have been informed in sufficient time of its intention to make the decision and shall afford to all such persons a reasonable opportunity of making representations to the authority with respect thereto.

See id. at 38. Principle number 3 states, "It shall be the duty of an authority in proceeding to a decision to take all reasonable steps to ascertain the facts which are material to the decision." Id. This document clarifies that "all reasonable steps" means measures by way of inquiry, verification, deliberation, or otherwise as are in all circumstances of the case necessary according to good administrative practice.

25. Committee of Justice, Patrick Neill, Chairman, A dministrative Justice: Some NecesSary Reforms (1988) [hereinafter Administrative Justice: Some Necessary Reforms].

26. Id. at 7 .

27. Id.

28. Id. at 8 . 
The report emphasizes the importance of having some principles of good administration and recommends that the British Ombudsman write a list of principles of good administration to guide administrative decisions. This list can be drawn up by each department by means of public rules. The report underlines that "[r]igidity should be avoided. The principles and any departmental rules or codes of practice should be drafted in such a way as to emphasize the importance of flexibility." ${ }^{29}$

A second clue about good administration comes from EC law, where we can find several legal documents that are concerned with good administration.

First, is the Resolution of September 28, 1977 of the Council of Europe, entitled, On the Protection of the Individuals in Relation to the Acts of Administrative Authorities. ${ }^{30}$ Although this legal text does not actually use the words "good administration," its spirit may be found therein. This Resolution sets out five principles: (1) the right to be heard, (2) the right to access information, (3) the right of assistance and representation, (4) the administrative obligation of stating reasons, and (5) the administrative obligation of indicating available remedies.

As far as the Recommendation entitled Concerning the Exercise of Discretionary Powers by Administrative Authorities, ${ }^{31}$ the words "good administration" do not appear, though there are a number of principles that attempt to promote good administrative decisions. Of note are the second and sixth basic principles, which establish that an administrative authority, when exercising discretionary powers, should comply with objectivity and impartiality, taking into account only the factors relevant to each particular case ${ }^{32}$ and its particular circumstances. ${ }^{33}$

As far as the European Court of Justice is concerned, it uses the words "good administration" but fails to define them. As General Attorney Simon Rozes's conclusions highlighted in the decision of October 29, 1981, there is a duty of good administration in Community institutions. But what does this mean? The study of case law shows that a general idea exists concerning good administration. Basically, before reaching a decision, Community institutions must follow proper procedure: hearing the people concerned; taking into account all the relevant factors and rejecting the irrelevant; weighing the interests involved; and

29. Id. at 23 (Recommendation No. 8).

30. Council of Europe, On the Protection of the Individuals in Relation to the Acts of Administrative Authorities, Res. 77(31) (Sept. 28, 1977).

31. Recommendation of the Comm. of Ministers, supra note 8.

32. Id. at 6 .

33. Id. at 7 . 
explaining why they chose one alternative over another ${ }^{34}$ In this sense, the European Court of First Instance (CFI) has been active in the implementation of a number of procedural obligations, as different European scholars have noted. ${ }^{35}$ Actually, the CFI's case law has imposed a set of principles guiding European Institutions: the right of access to information, the right to be heard, the principle of care, and the duty of giving reasons.

On the other hand, from a broader and more political point of view, the Commission's White Paper on European Governance was published in July 2001, after an intense process where European, national, and regional actors, as well as academics and European citizens, were consulted. ${ }^{36}$ This document identifies five principles of good governance: openness, participation, accountability, effectiveness, and coherence. ${ }^{37}$

This background has finally crystallized in the legal consecration of a right to good administration, now established in Article 41 of the Charter of Fundamental Rights of the European Union, ${ }^{38}$ which has been already applied by European case law ${ }^{39}$ and even national case law: ${ }^{40}$

Right to good administration

(1) Every person has the right to have his or her affairs handled impartially, fairly and within a reasonable time by the institutions and bodies of the Union.

34. It is important to underline that the Treaty Establishing the European Community, supra note 15 , art. 253 says that:

Regulations, directives and decisions adopted jointly by the European Parliament and the Council, and such acts adopted by the Council or the Commission, shall state the reasons on which they are based and shall refer to any proposals or opinions which were required to be obtained pursuant to this Treaty.

35. See Hanns Peter Nehl, Principles of Administrative Procedures in EC Law (1999); Jürgen Schwarze, Judicial Review of European Administrative Procedure, 49 Puв. L. 146 (2004).

36. European Governance: A White Paper, $\mathrm{COM}(01) 428$ final, available at http://europa.eu.int/ eur-lex/en/com/cnc/2001/com2001_0428en01.pdf (last visited Mar. 8, 2005).

37. Id. at 10.

38. Charter of Fundamental Rights of the European Union, art. 41, 2000 O.J. (C 364) 18.

39. E.g., Case T-54/99, Max.mobil Telekommunikation Service GmbH v. Commission, 4 C.M.L.R. 32 (2002); Case T-321/01, Internationaler Hilfsfonds eV v. Commission, 2003 O.J. (C 275) 43.

40. See, e.g., Customs and Excise Commissioners v. Pegasus Birds Ltd., 2004 S.T.C. 262; see also STS, Mar. 29, 2004 (R.J., No. 1849) (the first Spanish judicial decision referring to Article 41). 
(2) This right includes:

- the right of every person to be heard, before any individual measure which would affect him or her adversely is taken;

- the right of every person to have access to his or her file, while respecting the legitimate interests of confidentiality and of professional and business secrecy;

- the obligation of the administration to give reasons for its decisions.

(3) Every person has the right to have the Community make good any damage caused by its institutions or by its servants in the performance of their duties, in accordance with the general principles common to the laws of the Member States.

(4) Every person may write to the institutions of the Union in one of the languages of the Treaties and must have an answer in the same language.

Article 41 refers to the right to a diligent performance as part of good administration in the first section, and in the second, specifies a number of rights stemming from this right to good administration. Three of these rights include the right of access to information contained in the file, the right to be heard (the audi alteram partem rule), and the duty of giving reasons for the decisions made.

The text from Article 41 presents few novelties regarding what is set out in the Treaty, or in case law, and contains a number of loopholes. ${ }^{41}$ For example, it is surprising to note a lack of reference to the institution of the European Ombudsman, mentioned in an independent reference in Article 43, referring specifically to his work controlling maladministration:

Ombudsman: Any citizen of the Union and any natural or legal person residing or having its registered office in a Member State

41. Article 41 of the Charter of Fundamental Rights of the European Union, supra note 38, mentions nothing about transparency, good faith, or unjustifiable failure to exercise powers, besides the problems with its defensive approach, as will be explained shortly. 
has the right to refer to the Ombudsman of the Union cases of maladministration in the activities of the Community institutions or bodies, with the exception of the Court of Justice and the Court of First Instance acting in their judicial role. ${ }^{42}$

The lack of an explicit connection between Articles 41 and 43 must be underlined, especially because the European Ombudsman has been a fervent instigator of compliance with the Codes of Good Administration in European institutions. It is known that the European Ombudsman launched, on his own initiative, an inquiry about the existence of, and public accessibility to, such codes, recommending the adoption of rules concerning good administrative behavior. In 1999, the European Ombudsman recommended a draft Code of Good Administrative Behaviour to the Community institutions and bodies, drawing up guidelines for making the adoption of such a code easier. The European Ombudsman's efforts have finally crystallized in the Resolution of the European Parliament, adopted on September 6, 2001. This Resolution approved a Code of Good Administrative Behaviour aimed at the institutions and organs of the EU. A number of references to this document will shortly be made that seek to develop the right to good administration based on Article 41 of the Charter.

Another important aspect is the individualistic perspective of Article 41 regarding procedural participation, which boils down to a hearing "before any individual measure which would affect him or her adversely is taken." 43 Thus, public participation-through public hearings or similar devices-in procedures for elaborating general decisions (e.g., regulations) is not considered. This is a disappointing loophole because participation is a sensitive issue with regard to the development of the EC's public policies, which include transparency, equality, objectivity, democracy, and accountability. As some authors have underlined, the European and U.S. trajectories diverge notably in relation to this aspect, and a more detailed regulation should be established. ${ }^{44}$

The right provided by the Charter concerning good administration implies the explicit and visible confirmation of the existence of a legal duty for public authorities to be in the best position to be able to make appropriate decisions,

42. Id. art. 43.

43. Id. art. 41.

44. See infra Part IV; Equality and Diversity, infra note 150; Trans-Atlantic: Harlow Revisited, infra note 150 . 
thereby resulting in a common European inheritance. ${ }^{45}$ Therefore, this duty implies important support for the procedural issues, which have now passed to a higher position.

\section{Is it a Good Idea to Regulate Administrative Procedures? And if so, What is the Best Way to do it: The European Code of Good Administrative Behaviour}

Given what has been described above, citizens have good reasons to demand good administrative procedures in order to promote good administration, among other important values. But is it a good idea to regulate administrative procedures?

Cassese, in an interesting study, gives some reasons for regulation. ${ }^{46}$ It would be necessary, for example, (a) to guide administrative discretion (not just limiting it, but guiding it), (b) to restrain judicial power (avoiding new judicial burdens), or (c) to centralize the governance of citizens' rights.

With regard to the importance of administrative procedures to guide discretion, the judgment of the European Court of Justice of November 21, 1991:

It must be stated first of all that, since an administrative procedure entailing complex technical evaluations is involved, the Commission must have a power of appraisal in order to be able to fulfil its tasks.

However, where the Community institutions have such a power of appraisal, respect for the rights guaranteed by the Community legal order in administrative procedures is of even more fundamental importance. Those guarantees include, in particular, the duty of the competent institution to examine carefully and impartially all the relevant aspects of the individual case, the right of the person concerned to make his views known and to have an adequately reasoned decision. Only in this way can the Court verify whether the factual and

45. The European Convention on Human Rights, art. 6, opened for signature Nov. 4, 1950, entered into force Sept. 3, 1953, C.E.T.S. No. 005, is also relevant.

46. Sabino Cassese, Legislative Regulation of Adjudicative Procedures: An Introduction, 5 Eur. Rev. Pub. L. 16 (1993). 
legal elements upon which the exercise of the power of appraisal depends were present. ${ }^{47}$

With regard to restraint of judicial power, the idea is that courts cannot add new procedural requirements beyond those regulated. In the U.S. Supreme Court case Vermont Yankee Nuclear Power Corp. v. Natural Resources Defense Council, Inc., the Court pointed out that:

Absent constitutional constraints or extremely compelling circumstances the "administrative agencies should be free to fashion their own rules of procedure and to pursue methods of inquiry capable of permitting them to discharge their multitudinous duties."....

We have continually repeated this theme throughout the years, most recently in FPC v. Transcontinental Gas Pipe Line Corp., 423 U.S. 326, 96 S.Ct. 579, 46 L.Ed.2d 533 (1976), decided just two Terms ago. In that case, in determining the proper scope of judicial review of agency action under the Natural Gas Act, we held that while a court may have occasion to remand an agency decision because of the inadequacy of the record, the agency should normally be allowed to "exercise its administrative discretion in deciding how, in light of internal organization considerations, it may best proceed to develop the needed evidence and how its prior decision should be modified in light of such evidence as develops." Id., at 333, 96 S.Ct., at 583. We went on to emphasize:

At least in the absence of substantial justification for doing otherwise, a reviewing court may not, after determining that additional evidence is requisite for adequate review, proceed by dictating to the agency the methods, procedures, and time dimension of the needed inquiry and ordering the results to be reported to the court without opportunity for further consideration on the basis of the new evidence by the agency. Such a procedure clearly runs the

47. Case C-269/1990, Technische Universität München v. Hauptzollamt München-Mitte, 1991 E.C.R I-5469, Grounds of the Judgment, paras. 13-14 (emphasis added). 
risk of "propel[ling] the court into the domain which Congress has set aside exclusively for the administrative agency." SEC $v$. Chenery Corp., 332 U.S. 194, 196, 67 S.Ct. 1575, 91 L. Ed. 1995 $(1947) .^{48}$

Finally, with regard to the centralization of the governance of citizens' rights, Spain is a good example. The Spanish Constitution gives the national government the power to establish some common rules about administrative procedures applicable to all regional and local administrative bodies. ${ }^{49}$

But Cassese's article also considers reasons against regulation. Among them, we can identify: rigidity; the need for avoiding too much legal regulation by delegation to secondary regulation; the fact that parliamentary accountability works well enough; and the idea that Public Administration can regulate its own procedures by administrative regulations. In that sense, it is important to take into account that in the French and British cases, for example, there is not a complete and consistent regulation of administrative procedure. ${ }^{50}$ Probably some of Cassese's reasons can explain this lack of a code in those European countries.

In the British case, there are several recommendations about administrative procedures and good administration in a report of the Committee of the Justice-All Souls of 1988. The report emphasizes that legislative regulation is a good idea in only two cases: when guaranteeing the duty of giving reasons and providing a remedy where there is unreasonable or excessive delay.

I think that it is interesting to analyze some of Cassese's opinions about arguments against regulation. With regard to the idea that regulations are necessary to guarantee justice, it is possible to agree with that general formula, but how many regulations, and what kind? Here, we can identify the battle between rigidity and flexibility, or to express it in a more technical way, the battle between rules and principles. ${ }^{5 !}$ And we can find here the opposition judicial model versus the interest representation model as well-both of which are procedural.

48. Vermont Yankee Nuclear Power Corp. v. Natural Res. Def. Council, Inc., 435 U.S. 519, 543-45 (1978) (emphasis added) (citation omitted).

49. Constitución Española de 1978 pt. VIII, § 141, cl. 18 (Sp.).

50 . This does not mean, obviously, that there are no regulations or principles regarding procedural aspects in both countries.

51. See generally Carol Harlow, Codification of EC Administrative Procedures? Fitting the Foot to the Shoe or the Shoe to the Foot, 2 Eur. L.J. 3 (1996) (examining two models of codification characterized by rigidity and flexibility). 
The first model copies the judicial process, emphasizing defensive aspects, and the second model takes into account the impact of procedures and final decisions in policies, and promotes participation.

It is difficult to find a regulation where it is only possible to identify elements of just one model. Normally, regulations use elements of both models, with more or less a preponderance of one or the other. The relationship between both procedural models in the regulations will be taken up later when studying the solutions adopted by the European Code of Good Administrative Behaviour.

With respect to the other ideas explained before, it is important not to forget that parliamentary control has become increasingly politicized and that rulemaking is used infrequently by administrative agencies to discipline themselves. Finally, it is possible to conclude that a certain legal degree of procedural uniformity is necessary to get equality of rights in the same country. ${ }^{52}$

\section{The European Code of Good Administrative Behaviour}

In July 1999, the European Ombudsman recommended a draft Code of Good Administrative Behaviour to the Community institutions and bodies, as was explained earlier. This draft contained twenty-eight articles. The European Parliament approved a slightly modified version of this draft on September 6, 2001. During the European Parliament's deliberations on the Code of Good Administrative Behaviour (the Code), one member of this institution stated that "there are two important issues at stake here. First of all, promoting the rule of law and second showing respect for European citizens." 33 The European Parliament's aforementioned resolution calls on the European Commission to submit a proposal for a regulation containing the Code, to be based on Article 308 of the EC Treaty. ${ }^{54}$

52. But this is not the American choice, as it is known. In the American case there is a federal system without a common procedural code. The Administrative Procedure Act of 1946, 5 U.S.C. $\S \S 551-559$ (2005), is applied only to federal activities, although there is a model act inspired by it (which is not compulsory) copied by several states.

53. European Code of Good Administrative Behaviour, supra note 2, is a document that consists of 27 articles. This Code is intended to explain in more detail how the Charter's right to good administration should work in practice.

54. Treaty Establishing the European Community, supra note 15, art. 308:

If action by the Community should prove necessary to attain, in the course of the operation of the common market, one of the objectives of the Community, and this Treaty has not provided the necessary powers, the Council shall, acting unanimously on a proposal from the Commission and after consulting the European Parliament, take the appropriate measures. 
What is the real importance of the Code? Can it be regarded as the first codification of administrative procedure in EU? These are interesting questions.

Having seen the origin and aim of the Code, let us now analyze it, making some comments on different aspects. In order to develop the study, the articles of the Code will be connected with Article 41 of the Charter of Fundamental Rights of the EU.

With regard to the scope of application, the Code distinguishes between the personal and the material. For the personal, the Code provides that "it shall apply to all officials and other servants to whom the Staff Regulations and the Conditions of employment of other servants apply, in their relations with the public." 55 But the Code is also applicable to other persons working for the institutions and their administrations, such as persons employed under private law contracts, experts on secondment from national civil service, and trainees. ${ }^{56}$ This means that the boundary between public and private spheres is flexible and that the duty of good administration is not linked to the formal "status" of a specific person carrying out a public function but to its existence.

Focusing now on another issue, Article 2.3 provides that public "refers to natural and legal persons, whether they reside or have their registered office in a Member State or not." 57 This implies that non-European citizens are entitled to good administration, too. Thus, it must be emphasized that Arricle 41 of the Charter refers to "every person," and this means that everybody, in theory, is entitled to good administration. ${ }^{58}$

As for the material scope of its application, Article 3.1 establishes that the Code contains general principles of good administrative behavior, which apply to all relations between institutions, their administrations, and the public, unless they are otherwise governed by specific provisions. Conversely, the principles set out in this Code do not apply to the relations between an institution and its officials. These relations are governed by staff regulations.

After examining the scope of application, we now move on to examine a number of articles containing general principles. ${ }^{59}$ Article 4 is entitled "lawful-

55. European Code of Good Administrative Behaviour, supra note 2 , art. $2, \S 1$.

56. Id. art. $2, \S 2$.

57. Id. art. $2, \S 3$.

58. Charter of Fundamental Rights of the European Union, supra note 38, art. 41.

59. Articles 4,11 , and 12 of the European Code of Good Administrative Behavior, supra note 2 , contain general principles. 
ness," Article 11 "fairness," and Article 12 "courtesy." linked to the first part of Article 41.1 of the Charter. ${ }^{61}$

Additionally, several important principles may be found in the Code, which guide the way toward how public functions should be conducted. These principles are to be found in Article 5 (absence of discrimination), ${ }^{62}$ Article 6 (proportionality), ${ }^{63}$ Article 8 (impartiality and independence), ${ }^{64}$ Article 9 (objectivity), ${ }^{65}$ and Article 10 (legitimate expectations, consistency and advice). ${ }^{66}$ Let us now examine all these principles.

Article 5 concerns discrimination. ${ }^{67}$ It may be linked to Article 41.1 of the Charter, ${ }^{68}$ which refers to "impartiality," because impartiality implies absence of discrimination, ${ }^{69}$ in addition to Articles 20, 21, 22, 23, and 24 of the Charter. ${ }^{70}$ There is no discrimination when different treatment "is made... justified by the

60. European Code of Good Administrative Behaviour, supra note 2, art. 4 ("The official shall act according to law and apply the rules and procedures laid down in Community legislation. The official shall in particular take care that decisions which affect the rights or interests of individuals have a basis in law and that their content complies with the law."). Article 11 states: "The official shall act impartially, fairly and reasonably." Id. art. 11 . Article 12 states:

1. The official shall be service-minded, correct, courteous and accessible in relations with the public. When answering correspondence, telephone calls and e-mails, the official shall try to be as helpful as possible and shall reply as completely and accurately as possible to questions which are asked.

2. If the official is not responsible for the matter concerned, he shall direct the citizen to the appropriate official.

3. If an error occurs which negatively affects the rights or interests of a member of the public, the official shall apologise for it and endeavour to correct the negative effects resulting from his or her error in the most expedient way and inform the member of the public of any rights of appeal in accordance with Article 19 of the Code.

Id. art. 12.

61. Charter of Fundamental Rights of the European Union, supra note 38, art. 41, § 1.

62. European Code of Good Administrative Behaviour, supra note 2, art. 5.

63. Id. art. 6.

64. Id. art. 8.

65. Id. art. 9.

66. Id. art. 10.

67. Id. art. 5.

68. Charter of Fundamental Rights of the European Union, supra note 38, art. $41, \S 1$.

69. See European Code of Good Administrative Behaviour, supra note 2, arts. 8, 11 .

70. See Charter of Fundamental Rights of the European Union, supra note 38, arts. 20, 21-24. 
objective relevant features of the particular case." ${ }^{\text {71 }}$ Article 5.3 lists a number of causes of possible unjustified discrimination (but, obviously, this is not an exhaustive list). ${ }^{72}$ Among these causes can be found features concerning genetics, ${ }^{73}$ an issue that is becoming increasingly important.

Article 6 considers the principle of proportionality, ${ }^{74}$ one of the most useful tools to control administrative decisions. Proportionality is distinguished from objectivity, ${ }^{75}$ which is a fair distinction since both notions are different, as will be seen later in more detail. It is important to highlight that the abuse of power ${ }^{76}$ is also contained in a different article, another correct distinction. Abuse of power is defined as the use of powers "for purposes which have no basis in the law or which are not motivated by any public interest," "77 which is the desviacion de poder in the Spanish legal system (with techniques similar to other European legal systems).

Impartiality is the objective of Article $8 .^{78}$ This Article (and Article 7, which concerns the abuse of power ${ }^{79}$ ) is connected with the "fair" behavior mentioned in Article 41.1 of the Charter ${ }^{80}$ Article 8 prohibits partiality based on any grounds, explicitly including "personal, family or national interest or by political pressure." 81 On the other hand, it includes the obligation of abstention when an official (or any close member of his or her family) has a financial interest. ${ }^{82}$

Objectivity is distinguished from proportionality by Article $9 ;^{83}$ it is also distinguished from abuse of power, as discussed earlier. I agree with this decision,

71. European Code of Good Administrative Behaviour, supra note 2 , art. $5, \S 2$. This opens the door to the thorny subject of the possibility of "affirmative actions," which we are unable to cover here. For examples of equal treatment discussion, see Charter of Fundamental Rights of the European Union, supra note 38, at 16; Council Directive 2000/43/EC, art. 5, 2000 O.). (L 180).

72. European Code of Good Administrative Behaviour, supra note 2, art. 5 , $§ 3$.

73. Id.

74. Id. art. 6.

75. Id. art. 9.

76. Id. art. 7.

77. Id.

78. Id. art. 8.

79. Id. art. 7 ("Powers shall be exercised solely for the purposes for which they have been conferred by the relevant provisions. The official shall in particular avoid using those powers for purposes which have no basis in the law or which are not motivated by any public interest.").

80. Charter of Fundamental Rights of the European Union, supra note 38, art. $41, \S 1$.

81. European Code of Good Administrative Behaviour, supra note 2 , art. $8, \S 2$.

82. Id. But, could an individual challenge an official due to his or her relationships? Article 8 says nothing about this subject, but it seems reasonable to understand that it could be a possible alternative.

83. Id. art. 9. 
because although these concepts are linked to the consideration of the final decision, proportionality and abuse of power are limits and barriers to administrative activities, while objectivity is a positive guide for officials. In this sense, we believe that the second paragraph of Article $6^{84}$ should be contained in Article 9 as part of the duty to act objectively.

In the case of objectivity (also linked to fair behavior in Article 41 of the Charter), this principle imposes a duty to take "into consideration the relevant factors and give each of them its proper weight in the decision, whilst excluding any ir relevant element from consideration. ${ }^{85}$ In my view, this duty is equivalent to the principle of care elaborated by case law at the CFI, as was seen above.

Article 10 should also be considered in order to conclude this section on principles. This article provides three different guides on consistency, legitimate expectations, and advice:

(1) The official shall be consistent in his own administrative behaviour as well as with the administrative action of the Institution. The official shall follow the Institution's normal administrative practices, unless there are legitimate grounds for departing from those practices in an individual case; these grounds shall be recorded in writing.

(2) The official shall respect the legitimate and reasonable expectations that members of the public have in the light of how the Institution has acted in the past.

(3) The official shall, where necessary, advise the public on how a matter which comes within his or her remit is to be pursued and how to proceed in dealing with the matter. ${ }^{86}$

The first paragraph is connected with the fair behavior mentioned in Article 41 of the Charter. It is also linked to the principle of objectivity, in the sense that the official shall take into account the institution's normal practices, and shall give

84. Id. art. $6, \S 2$ ("When taking decisions, the official shall respect the fair balance between the interests of private persons and the general public interest.").

85. Id. art. 9.

86. Id. art. 10. 
them their proper weight in the decision. This means that a public policy can only be changed on the basis of serious grounds, which shall be explained in writing in order to control its actual existence. Thus, a relationship can be found between this provision and Articles 18 (duty to state the grounds for decisions) ${ }^{87}$ and 24 (duty to keep adequate records). ${ }^{88}$ This issue will be mentioned later.

The second paragraph in Article 10, concerning legitimate and reasonable expectations, ${ }^{89}$ may be linked to Article 41.3 of the Charter. ${ }^{90}$ Therefore, a consequence of breaching Article 10.2 will be compensation for damages occurring as a result of maladministration. Finally, Article 10.3 is linked to Articles 19 and 23, in the sense that all of them deal with public advice to citizens. ${ }^{91}$

If we now move to another section of Articles in the Code, it will be seen that Articles 13, 14, and 15 share common elements. Article 13 develops Article 41.4 of the Charter, with regard to the use of languages before the European institutions and bodies. ${ }^{92}$ Article 14 establishes that:

87. Id. art. 18.

88. Id. art. 24.

89. Id. art. $10, \S 2$.

90. Charter of Fundamental Rights of the European Union, supra note 38, art. $41, \S 3$.

91. European Code of Good Administrative Behaviour, supra note 2, art. 19. Article 19: Indication of the Possibilities of Appeal

1. A decision of the Institution which may adversely affect the rights or interests of a private person shall contain an indication of the appeal possibilities available for challenging the decision. It shall in particular indicate the nature of the remedies, the bodies before which they can be exercised, as well as the time-limits for exercising them.

2. Decisions shall in particular refer to the possibility of judicial proceedings and complaints to the Ombudsman under the conditions specified in, respectively, Articles 230 and 195 of the Treaty establishing the European Community.

Article 23: Requests for Public Access to Documents

1. The official shall deal with requests for access to documents in accordance with the rules adopted by the Institution and in accordance with the general principles and limits laid down in Regulation (EC) No 1049/2001.

2. If the official cannot comply with an oral request for access to documents, the citizen shall be advised to formulate it in writing.

Id. art. 23 (citation omitted).

92. The official shall ensure that every citizen of the Union or any member of the public who writes to the Institution in one of the Treaty languages receives an answer in the same language. The same shall apply as far as possible to legal persons such as associations (NGOs) and companies.

Id. art. 13. 
(1) Every letter or complaint to the Institution shall receive an acknowledgement of receipt within a period of two weeks, except if a substantive reply can be sent within that period.

(2) The reply or acknowledgement of receipt shall indicate the name and the telephone number of the official who is dealing with the matter, as well as the service to which he or she belongs.

(3) No acknowledgement of receipt and no reply need be sent in cases where letters or complaints are abusive because of their excessive number or because of their repetitive or pointless character. ${ }^{93}$

Finally, Article 15 is a clear expression of the fight against formalism. It imposes the obligation of transferring to the competent service the letters or complaints received, instead of merely rejecting them.

Now, with regard to another group of articles, the relationship between Articles 10.3, 19,22, and 23 is clear. All of these articles deal with advice and information to the public, and are linked to the idea of transparency. ${ }^{94}$

93. Id. art. 14.

94. Id. art. 10, para. 3 ("The official shall, where necessary, advise the public on how a matter which comes within his or her remit is to be pursued and how to proceed in dealing with the matter."). Additionally, Art. 19 states:

1. A decision of the Institution which may adversely affect the rights or interests of a private person shall contain an indication of the appeal possibilities available for challenging the decision. It shall in particular indicate the nature of the remedies, the bodies before which they can be exercised, as well as the time-limits for exercising them.

2. Decisions shall in particular refer to the possibility of judicial proceedings and complaints to the Ombudsman under the conditions specified in, respectively, Articles 230 and 195 of the Treaty establishing the European Community.

Id. art. 19. Art. 22 states:

1. The official shall, when he has responsibility for the matter concerned, provide members of the public with the information that they request. When appropriate, the official shall give advice on how to initiate an administrative procedure within his field of competence. The official shall take care that the information communicated is clear and understandable.

2. If an oral request for information is too complicated or too comprehensive to be dealt with, the official shall advise the person concerned to formulate his demand in writing. 
Following this analysis of the Code, we may now move on to Article 16:

(1) In cases where the rights or interests of individuals are involved, the official shall ensure that, at every stage in the decisionmaking procedure, the rights of defense are respected.

(2) Every member of the public shall have the right, in cases where a decision affecting his rights or interests has to be taken, to submit written comments and, when needed, to present oral observations before the decision is taken. ${ }^{95}$

Article 16 is linked to Article $41.2^{96}$ of the Charter, and to Articles 10.2, ${ }^{97} 18$, and $24 .{ }^{98}$ If we compare Article 16 with Article 41 of the Charter, it seems that the Code goes even further than the Charter. As I explained above, the Charter focuses on the role of participation as a tool of defense. Although this approach may be found in Article 16.1, the second paragraph includes a new and interesting development. Article 16.2 refers to the "public," not "individuals." 99 There is a right to submit written comments and to present oral observations "when

3. If, because of its confidentiality, an official may not disclose the information requested, he or she shall, in accordance with Article 18 of this Code, indicate to the person concerned the reasons why he cannot communicate the information.

4. Further to requests for information on matters for which he has no responsibility, the official shall direct the requester to the competent person and indicate his name and telephone number. Further to requests for information concerning another Community institution or body, the official shall direct the requester to that institution or body.

Id. art. 22. And Art. 23 states:

1. The official shall deal with requests for access to documents in accordance with the rules adopted by the Institution and in accordance with the general principles and limits laid down in Regulation (EC) No 1049/2001.

2. If the official cannot comply with an oral request for access to documents, the citizen shall be advised to formulate it in writing.

Id. art. 23 (citation omitted).

95. Id. art. 16.

96. Charter of Fundamental Rights of the European Union, supra note 38, art. 41, § 2.

97. European Code of Good Administrative Behaviour, supra note 2, art. $10, \S 2$.

98. Id. arts. 18, 24.

99. Id. art. $16, \S 2$. 
needed"; 100 this is an undefined legal concept, to be applied case by case, prior to a specific assessment, through activities such as public hearings or similar forums. The right of a member of the public to be heard exists "in cases where a decision affecting his rights or interests" will be made. ${ }^{101}$ But there is no right mentioned with regard to obtaining reasoned answers to the comments and observations made, although we might be able to find it by applying Article $14 .^{102}$

Article 16.2 introduces a promising device to promote democracy, transparency, and equality, and is a useful tool to improve general administrative decisions by means of obtaining better data concerning the facts and interests involved. This kind of participation may be able to provide a voice for collective and social interests (e.g., the environment). ${ }^{103}$ The reasonable time limit for making decisions is two months from the date of receipt of any request or complaint. ${ }^{104}$

With regard to Article 18 and the duty to state the grounds for decisions made, ${ }^{105}$ we must recall Article 253 of the aforementioned Treaty and European case law. Article 18 states that:

(1) Every decision of the Institution which may adversely affect the rights or interests of a private person shall state the grounds on which it is based by indicating clearly the relevant facts and the legal basis of the decision.

(2) The official shall avoid making decisions which are based on brief or vague grounds or which do not contain individual reasoning.

(3) If it is not possible, because of the large number of persons concerned by similar decisions, to communicate in detail the grounds of the decision and where standard replies are therefore made, the

100. Id.

101. Id.

102. Art. 86 of the Spanish Common Administrative Procedure Act (1992) (providing an actual right to obtain reasoned answers to observations submitted by means of the informaciones públicas).

103. As regards the importance of public participation in administrative procedures, see the interesting decision made by the Spanish Constitutional Court, STC, July 17, 1995, R.T.C., No. 119.

104. European Code of Good Administrative Behaviour, supra note 2, art. 17, $\S 1$. Thus, this Article has to be linked to Art. 6.1 of the European Convention on Human Rights, taking into account Art. 53 of the Charter.

105. Id. art. 18. 
official shall guarantee that he subsequently provides the citizen who expressly requests it with an individual reasoning. ${ }^{106}$

This duty, that is, the principle of objectivity, ${ }^{107}$ and the duty to keep proper records ${ }^{108}$ are linked. Thus, (a) the administrative procedure, (b) the record where all the activities are put down on paper making them "visible," (c) the final decision itself, and (d) the grounds that support it, are elements of a global system with different interactions. And this system is ruled by the idea of consistency, ${ }^{109}$ an expression of the principle of rationality. Thus, the documents included in the record (e.g., the answers to comments or observations made by the public), the content of the final decision, and the reasons given must be consistent and follow a rational link.

The record and the reasons stated are similar to the black box in planes, but in relation to administrative procedures: a place where everybody (including the judge in the event of controls) can check what has happened, what was well done, and what was overlooked, or done badly. ${ }^{130}$ In other words, officials must prove that good administration has been conducted by means of records kept and reasons given, and this means that public administration has the burden of proof as regarding good administration.

Article 18 lacks a reference to the necessity of explaining clearly the criteria used to make the decision. ${ }^{111}$ Criteria are important elements, especially when using discretionary powers. ${ }^{112}$ Moreover, Article 18 should include all kinds of discretionary decisions, even though they do not adversely affect a private person because of the principle of transparency and the need to guarantee good administration. ${ }^{13}$

106. Id.

107. Id. art. 9.

108. Id. art. 24.

109. Id. art. $10, \S 1$.

110. The American "hard look" doctrine is based, as was seen earlier, on the judicial review of the record and the explanations given by the officials, trying to ascertain whether good use of public powers was made.

111. European Code of Good Administrative Behaviour, supra note 2, art. 18.

112. Art. 39 of the German Administrative Procedure Act (1976) provides for the need to explain the criteria that could guide the final discretionary decision.

113. See, e.g., Art. 54 of the Spanish Common Administrative Procedure Act (1992). 
Continuing with the study of the Code, Article 20 deals with notification of decisions ${ }^{114}$ and Article 21 with data protection. ${ }^{115}$ Articles 22, 23, and $24^{116}$ are linked to Article 41.2 of the Charter, which provides a right to access one's own file. ${ }^{117}$ However, Article 24 lays down a basic duty to allow for exercising other rights, such as the right to access files. ${ }^{118}$ This Article requires keeping adequate records and may be linked to Articles 9 (objectivity) ${ }^{119}$ and 18 (duty to give reasons). ${ }^{120}$ Only by means of a good record can institutions prove that they have followed a due process. Consequently, only a good record can guarantee the actual functioning of a good administration. Therefore, the European Ombudsman and the courts should control the records, as well as the reasons given, carefully. ${ }^{121}$

Finally, Article 27 reads: "Each [i]nstitution shall review its implementation of the Code after two years of operation and shall inform the European Ombudsman of the results of its review."122

A future regulation of the Code should be an opportunity to improve it. Therefore, I shall simply recommend a number of ideas:

- To add a general principle of good faith to relationships between officials and citizens; $;^{123}$

- To promote public participation as a way of achieving greater transparency, democracy, equality, and sound administration, especially in relation to general decisions affecting groups of unknown people-asking for rea-

114. European Code of Good Administrative Behaviour, supra note 2, art. 20.

115. Id. art. 21.

116. Id. arts. 22-24.

117. Charter of Fundamental Rights of the European Union, supra note 38, art. $41, \S 2$.

118. European Code of Good Administrative Behaviour, supra note 2, art. 24.

119. Id. art. 9.

120. Id. art. 18.

121. Regarding the Ombudsman's activities, see the European Code of Good Administrative BeHaviour, supra note 2, arts. 19,26. The Charter presents a problem in relation to the entitlement to file a complaint before the European Ombudsman. Article 21 of the Treaty Establishing the European Community, supra note 15, provides European citizens and people residing or having a registered office in the EU the chance to file a complaint before the Ombudsman. But currently, the European Code of Good Administrative Behaviour, supra note 2, art. 2, cl. 3, extends the right to good administration to everybody, whether residing or having a registered office in the European Union or not. Thus, it seems that it would be a common right for European citizens, residents, and others, but only the first two groups of people would be able to file a complaint before the European Ombudsman.

122. European Code of Good Administrative Behaviour, supra note 2, art. 27.

123. See Art. 3 of the Spanish Common Procedure Act (1992). 
soned (and reasonable) answers to citizen's comments, and to make their efforts worth while;

- To require institutions and bodies to automatically identify the official responsible for the proceedings, following the Italian example. ${ }^{124}$

\section{Who or What Should Regulate Administrative Procedure?}

We must take into account different actors: the Constitution; Parliament, by statutes; administrative agencies, using an ad hoc basis or general principles; and courts, by means of judicial review. I will analyze briefly each possibility.

First, some European national constitutions regulate administrative procedures in some way, such as Article 105 of the Spanish Constitution. ${ }^{125}$

The American Constitution has an interesting element. ${ }^{126}$ At the constitutional level, the Due Process clause is not concerned with good government. ${ }^{127}$ Due process, as interpreted by the U.S. Supreme Court, is simply a defensive tool, intended to protect citizens. For it to work, due process needs an entitlement, that is, a right given by the legal system to an individual. As has been pointed

124. See Art. 4 of the Italian Administrative Procedure Act (1990). Currently, the European Code of Good Administrative Behaviour, supra note 2 , art. 14, cl. 2, provides for the identification of the official responsible only in proceedings started by a private person, but does not say anything about ex officio proceedings.

125. The law shall regulate:

a) The hearing of citizens, directly or through the organizations and associations recognised by the law, in the process of elaborating the administrative decisions which affect them;

b) access by the citizens to the administrative archives and registers except where it affects the security and defence of the State, the investigation of crimes, and the privacy of persons; and

c) the procedure for administrative actions and for guaranteeing when appropriate the hearing of interested persons.

Constitución Española de 1978, supra note 23, pt. 4, § 105 (Sp.) (author's translation).

126. The U.S. case law shows a special sensibility for procedural aspects. In McNabb v. United States, 318 U.S. 332, 347 (1943), Justice Frankfurter said, "The history of liberty has largely been the history of observance of procedural safeguards," and in Shaughnessy $v$. United States, 345 U.S. 206, 224 (1953), Justice Jackson said, "Procedural fairness and regularity are of the indispensable essence of liberty. Severe substantive laws can be endured if they are fairly and impartially applied."

127. Neither the states nor the Federal Government can deprive any person "of life, liberty, or property, without due process of law." See U.S. Const. amends. V, XIV (emphasis added). 
out, if there is a discretionary power, there is not an entitlement: there is unfettered discretion, and consequently due process fails to work. ${ }^{128}$

In the United States, the Administrative Procedure Act (APA) plays an important role, but in relation to informal adjudication procedures, the APA is virtually silent. Informal procedures comprise roughly 90 percent of all administrative procedures; in relation to those procedures, the due process requirements will work sometimes, but not always. The main actor here is judicial power, which demands tough procedural requirements, as we have seen before, and is even asking for new activities not to be established by the legislator.

What is the reason for constitutional attention to procedural issues? Values such as democracy, accountability, good administration, protection of rights, and effective judicial review respecting the functional distinction of powers can justify this constitutional interest. As Cassese points out: "[L]egislative regulation of administrative procedure has been a major turning point in the history of many Constitutions (e.g., the U.S. Constitution) and looks like an essential requisite of good administration." 129

Regarding protection of rights, it is necessary to emphasize that administrative procedures make fundamental rights work. Thus, the double perspective of fundamental rights is clear: they are both procedural and substantial. From that point of view, administrative procedures are a constitutional element, linked to constitutional rights. That relationship has been underlined both by European case law at the national level and by the European Court of Human Rights.

At the national level, the German Constitutional Court's decision MülheimKärlich is well-known. In that decision, the German Constitutional Court declared that basic rights must be protected by procedure, which is significant to ensure its effective protection.

The European Court of Human Rights has also emphasized the relevance of procedural aspects for protecting rights in several cases (e.g., McMichael, ${ }^{130}$

128. For example, due process requirements are not applicable to regulations. See Bi-Metallic Inv. Co. v. Colorado, 239 U.S. 441 (1915); see also Tim Searchinger, The Procedural Due Process Approach to Administrative Discretion: The Court's Inverted Analysis, 95 YALE L.J. 1017 (1986) (discussing the paradox caused by the interpretation that where there is more discretionary power, there is less of a need for process).

129. Cassese, supra note 46, at 20.

130. McMichael v. United Kingdom, 307 Eur. Ct. H.R. 27, 57 (1995). In McMichael, the applicants were a couple with serious mental problems who had a child. The social work department, after following legal procedures which included several hearings, decided that they were unable $\mathrm{mmmm}$ 
Buckley, ${ }^{131}$ and Chapman). Chapman presents another interesting element: the relationship between rights and procedures includes civil and political

to take care of their child and the public authority granted an order freeing the child for adoption, against the will of the biological parents. The parents brought an action before the European Court of Human Rights. The Court stated that Articles 6 and 8 of the convention had been breached. As regards Article 6.1, the lack of access to certain documents during proceedings violated the right to a "fair hearing." (Article 255 of the Treaty and Article 41 of the Charter). Regarding Article 8, public authorities did not respect "private family life" because the lack of a "fair procedure":

91. As to the Government's second submission, the Court would point to the difference in the nature of the interests protected by Articles 6(1) and 8. Thus, Article 6(1) affords a procedural safeguard, namely the "right to a court" in the determination of one's "civil rights and obligations" [See Golder v. United Kingdom (A/18): 1 E.H.R.R. 524, para. 36.]; whereas not only does the procedural requirement inherent in Article 8 cover administrative procedures as well as judicial proceedings, but it is ancillary to the wider purpose of ensuring proper respect for, inter alia, family life. [See, for example, B. v. United Kingdom (A/121-B): (1988) 10 E.H.R.R. 87, paras. 63-65 and 68.] The difference between the purpose pursued by the respective safeguards afforded by Arricles 6(1) and 8 may, in the light of the particular circumstances, justify the examination of the same set of facts under both Articles. [Compare, for example, Golder v. United Kingdom, loc. cit., paras. $41-45$ and O. v. United Kingdom (A/120-A): (1988) 10 E.H.R.R. 82, paras. 65-67.]

As regards the instant case, the facts complained of had repercussions not only on the conduct of judicial proceedings to which the second applicant was a party, but also on "a fundamental element of [the] family life" of the two applicants. [See para. 85 above.] In the present case the Court judges it appropriate to examine the facts also under Article 8.

92. The Government have already conceded, in the context of Article 6(1), the unfair character of the care proceedings on specified occasions by reason of the inability of the second applicant or the first applicant acting as her representative to have sight of certain documents considered by the children's hearing and the Sheriff Court. [See paras. 79 and 81 above.]

The Court, taking note of this concession, finds that in this respect the decisionmaking process determining the custody and access arrangements in regard to $\mathrm{A}$ did not afford the requisite protection of the applicants' interests as safeguarded by Article 8.

Id. paras. $91-92$.

131. Buckley v. United Kingdom, 1996-IV Eur. Ct. H.R. 1271, 1292-93. In Buckley, a Gypsy citizen who lived in a caravan applied for planning permission to a local government to regularize her legal situation. The application was refused according to the Town and County Planning Act 1990 and the local authority issued an enforcement notice, which was not complied with by the $\mathrm{mmm}$ 
rights as well as social rights. ${ }^{132}$ So, an unfair procedure can breach a social right too.

Gypsy citizen. She brought an action before the European Court of Human Rights, claiming a breach of Article 8 of the Convention. Although the Court decided that Article 8 was not violated (with several dissenting opinions), it established an interesting doctrine about the relationship among discretion, procedures and rights:

75. The Court has already had the occasion to note that town and country planning schemes involve the exercise of discretionary judgment in the implementation of policies adopted in the interest of the community. [In the context of Art. 6(1), see Bryan v. United Kingdom, loc. cit., para. 47; in the context of Art. 1 of Protocol No. 1, see Sporrong and Lönnroth v. Sweden (A/52): (1983) 5 E.H.R.R. 35, para. 69; Erkner and Hofauer v. Austria (A/117): (1987) 9 E.H.R.R. 464, paras. 74-75 and 78; Poiss v. Austria (A/117): (1988) 10 E.H.R.R. 231, paras. 64-65 and 68; Jacobsson v. Sweden (A/163): (1990) 12 E.H.R.R. 56, paras. 57 and 63.] It is not for the Court to substitute its own view of what would be the best policy in the planning sphere or the most appropriate individual measure in planning cases. [See, Mutatis Mutandis, Klass v. Germany (A/28): 2 E.H.R.R. 214, para. 49.] By reason of their direct and continuous contact with the vital forces of their countries, the national authorities are in principle better placed than an international court to evaluate local needs and conditions. In so far as the exercise of discretion involving a multitude of local factors is inherent in the choice and implementation of planning policies, the national authorities in principle enjoy a wide margin of appreciation.

76. The Court cannot ignore, however, that in the instant case the interests of the community are to be balanced against the applicant's right to respect for her "home", a right which is pertinent to her and her children's personal security and well-being. [See Gillow v. United Kingdom, loc. cit., para. 55.] The importance of that right for the applicant and her family must also be taken into account in determining the scope of the margin of appreciation allowed to the respondent State.

Whenever discretion capable of interfering with the enjoyment of a Convention right such as the one at issue in the present case is conferred on national authorities, the procedural safeguards available to the individual will be especially material in determining whether the respondent State has, when fixing the regulatory framework, remained within its margin of appreciation. Indeed it is settled case law that, whilst Article 8 contains no explicit procedural requirements, the decision-making process leading to measures of interference must be fair and such as to afford due respect to the interests safeguarded to the individual by Article 8 . [See McMichael v. United Kingdom (A/308): (1995) 20 E.H.R.R. 205, para. 87.]

Id. paras. $75-76$.

132. Chapman v. United Kingdom, 2001-I Eur. Ct. H.R. 41, 71-72. In Chapman, the facts were very similar. As regards a possible violation of Article 8 , finally discarded:

90. An interference will be considered "necessary in a democratic society" for a legitimate aim if it answers a "pressing social need" and, in particular, if it is $\mathrm{mmmmm}$ 
In Chapman the majority held that:

It is important to recall that Article 8 does not in terms recognise a right to be provided with a home. Nor does any of the jurisprudence of the Court acknowledge such a right. While it is clearly desirable that every human being have a place where he or she can live in dignity and which he or she can call home, there are unfortunately in the Contracting States many persons who have no

proportionate to the legitimate aim pursued. While it is for the national authorities to make the initial assessment of necessity, the final evaluation as to whether the reasons cited for the interference are relevant and sufficient remains subject to review by the Court for conformity with the requirements of the Convention. [See, amongst other authorities, Lustig-Prean and Beckett v. United Kingdom: (2000) 39 E.H.R.R. 548, paras 80-81.]

91. In this regard, a margin of appreciation must, inevitably, be left to the national authorities, who by reason of their direct and continuous contact with the vital forces of their countries are in principle better placed than an international court to evaluate local needs and conditions. This margin will vary according to the nature of the Convention right in issue, its importance for the individual and the nature of the activities restricted, as well as the nature of the aim pursued by the restrictions. [See Dudgeon v. United Kingdom loc. cit., para. 52, and Gillow v. United Kingdom (A/109): (1989) 11 E.H.R.R. 335, para. 55.]

92. The judgment in any particular case by the national authorities that there are legitimate planning objections to a particular use of a site is one which the Court is not well equipped to challenge. It cannot visit each site to assess the impact of a particular proposal on a particular area in terms of impact on beauty, traffic conditions, sewerage and water facilities, educational facilities, medical facilities, employment opportunities and so on. Because planning inspectors visit the site, hear the arguments on all sides and allow examination of witnesses, they are better situated than the Court to weigh the arguments. Hence, as the Court observed in Buckley, [loc. cit., para. 75 in fine.] "in so far as the exercise of discretion involving a multitude of local factors is inherent in the choice and implementation of planning policies, the national authorities in principle enjoy a wide margin of appreciation," although it remains open to the Court to conclude that there has been a manifest error of appreciation by the national authorities. In these circumstances, the procedural safeguards available to the individual applicant will be especially material in determining whether the respondent State has, when fixing the regulatory framework, remained within its margin of appreciation. In particular, it must examine whether the decision-making process leading to measures of interference was fair and such as to afford due respect to the interests safeguarded to the individual by Article 8. [See Buckley v. United Kingdom loc cit., paras 76-77.]

Id. paras. 90-92. 
home. Whether the State provides funds to enable everyone to have a home is a matter for political not judicial decision. ${ }^{133}$

But the dissenting opinion of several judges held that:

We would also take issue with the relevance or validity of the statement in paragraph 99 of the judgment to the effect that Article 8 does not recognise a right to be provided with a home. In this case, the applicant had a home, in her caravan on her land, but was being prevented from settling there. Furthermore, it is not the Court's case law that a right to be provided with a home is totally outside the ambit of Article 8. The Court has accepted that there may be circumstances where the authorities' refusal to take steps to assist in housing problems could disclose a problem under Article 8-see, for example, Marzari, cited above, where the Court held that a refusal of the authorities to provide housing assistance to an individual suffering from a serious illness might in certain circumstances raise an issue because of the impact of such refusal on the private life of the individual. Obligations on the State arise therefore where there is a direct and immediate link between the measures sought by an applicant and the latter's private life (see Botta v. Italy, judgment of 24 February 1998, Reports 1998-I, p. $422, \S \S 33-34) .{ }^{134}$

And last but not least, effective judicial review, respecting the functional distinction of powers, is also a constitutional issue. In that sense, the U.S. Supreme Court stated in 1984 in the Cheuron case:

Judges are not experts in the field [being regulated], and are not part of either political branch of government. Courts must, in some cases, reconcile competing political interests, but not on the basis of the judges' personal policy preferences.... While agencies are not directly accountable to the people, the Chief Executive

133. Chapman, 2001-I Eur. Ct. H.R. at 73.

134. Id. at 86. 
is, and it is entirely appropriate for this political branch of the Government to make such policy choices. ${ }^{135}$

The same idea, without forgetting the different institutional model, may be found in the European context. For example, the Spanish Supreme Court has established in several decisions that when there is discretionary power there is always a nucleus of freedom, and in choosing from among several possible solutions, all of them legal, judicial review cannot change administrative assessment. ${ }^{136}$

Consequently, administrative procedures can guide the administrative decision, contributing to an increase in its quality. This function is out of the judicial possibilities according to the constitutional limits connected to the division of powers existing in the rule of law systems. In that sense, judicial review of administrative procedures is a way of controlling good administration without breaking constitutional requirements.

Finally, we must take into account that the new treaty establishing an European constitution, which has recently been signed by EU leaders, has incorporated the right to good administration. ${ }^{137}$ This means that Europe will have its own constitutional Due Process clause, which will not be exactly the same as the U.S. Due Process clause, because the European version goes beyond defensive elements.

In addition to constitutions, parliaments could play an important role in codifying administrative procedure by statutes. Several European countries already have statutes in place. ${ }^{138}$ Administrative agencies can regulate their own procedures. This mechanism is recommended by the aforementioned JusticeAll Souls report. ${ }^{139}$

Finally, courts can regulate administrative procedures indirectly by means of judicial review, which means they can, at least indirectly, promote good administration. Even where there is a legislative regulation, judges establish procedural standards when resolving cases (e.g., the duty of giving reasons).

135. Chevron U.S.A., Inc. v. Natural Res. Def. Council, Inc., 467 U.S. 837, 865 (1984). Note also, that the U.S. Congress is accountable to the people.

136. See, e.g., STS, July 24, 1987 (R.J., No. 7671) (Spanish Supreme Court decision).

137. See Draft of the Treaty Establishing a Constitution for Europe, 2003 O.J. (C 169). The Treaty was signed October 29, 2004.

138. Spanish Common Administrative Procedure Act (1992); German Administrative Procedure Act (1976); Italian Administrative Procedure Act (1990).

139. Administrative Justice: Some Necessary Reforms, supra note 25. 
The limits in the review of discretionary powers make administrative procedures important. Courts can defend individual rights and collaborate in good administration without breaching the principle of functional distinction through their reviewing procedural aspects.

A good example of this idea can be found in the United States. At the legal level, the important APA establishes a procedural framework for federal agencies. In relation to rulemaking, where the discretionary power is wider, case law has expanded the requirements necessary in order to achieve good decisions. Since the 1970s, the courts, even the U.S. Supreme Court, have demanded that agencies act carefully, paying special attention to the relevant factors and interests involved. Case law has established the duty to listen to citizens, the duty to answer their comments by means of a statement of reasons, and the duty to study carefully the regulation before deciding, as ways of ensuring sound rules. This judicial approach is known as the "hard look" doctrine. ${ }^{140}$

However, judicial pressure has burdened the U.S. administrative law system, as pointed out by many authors. Discretionary decisions have a high rate of judicial challenges and a high rate of being overturned. Courts are establishing heavy procedural burdens and demanding more than a hundred pages of explanation in order to uphold a rule. Some voices have emphasized that there is judicial activism and that the necessary self-restraint, which is required by the principle of separation of powers, has disappeared. Several professors claim that judicial review is causing delays and is a waste of time and money, paralyzing public policy in some sectors and threatening public interests like health and environmental protection. This phenomenon is known as ossification. ${ }^{141}$

140. See, e.g., Harold Leventhal, Environmental Decisionmaking and the Role of the Courts, $122 \mathrm{U}$. PA. L. Rev. 509 (1974); William F. Pedersen, Jr., Formal Records and Informal Rulemaking, 85 Y ALE L.J. 38 (1975); J. Skelly Wright, New Judicial Requisites for Informal Rulemaking: Implications for the Environmental Impact Statement Process, 29 Admin. L. Rev. 59 (1977); Stephen G. Breyer \& Richard B. Stewart, Administrative Law and Regulatory Policy: Problems, Text and Cases 351 (1992).

141. See, e.g., Kenneth C. Davis \& Richard J. Pierce, Jr., Administrative Law Treatise $\$ 7.4$ (3d ed. 1994); Thomas O. McGarity, Some Thoughts on "Deossifying" the Rulemaking Process, 41 Duke L.J. 1385 (1992); Thomas O. McGarity, On Making Judges Do the Right Thing, 44 Duke L.J. 1104 (1995); Thomas O. McGarity, The Courts and the Ossification of Rulemaking: A Response to Professor Seidenfield, 75 Tex. L. Rev. 525 (1997); Richard J. Pierce, Jr., The Unintended Effects of Judicial Review of Agency Rules: How Federal Courts Have Contributed to the Electricity Crisis of the 1990s, 43 Admin. L. Rev. 7 (1991); Richard J. Pierce, Jr., Legislative Reform of Judicial Review of mmmmm 
The U.S. example shows that judicial review is important and necessary to guarantee good administration, but, at the same time, paradoxically, it can be a contributing factor in generating maladministration. To avoid such paradoxes, the main point about judicial review is the scope of procedural defects. Its regulation has to balance procedural fairness and efficiency, avoiding unnecessary delays and costs but guaranteeing protection and good administration.

Article 230 of the EC Treaty establishes that:

The Court of Justice shall review the legality of acts adopted jointly by the European Parliament and the Council, of acts of the Council, of the Commission and of the ECB, other than recommendations and opinions, and of acts of the European Parliament intended to produce legal effects vis-à-vis third parties.

It shall for this purpose have jurisdiction in actions brought by a Member State, the European Parliament, the Council or the Commission on grounds of lack of competence, infringement of an essential procedural requirement, infringement of this Treaty or of any rule of law relating to its application, or misuse of powers. ${ }^{142}$

Obviously, the problem is to distinguish between essential and nonessential procedural requirements. Schwarze points out that procedural requirements hardly can be classified as essential or nonessential, and that an essential infringement is normally given when the infringement may possibly have influenced the result of the administrative procedure or when the procedural requirement in question is supposed to protect the individual's rights. ${ }^{143} \mathrm{He}$

Agency Actions, 44 Duke L.J. 1110 (1995); Richard J. Pierce, Jr., Seven Ways to Deossify Agency Rulemaking, 47 Admin. L. Rev. 59 (1995); Richard J. Pierce, Jr., Judicial Review of Agency Actions in a Period of Diminishing Agency Resources, 49 Admin. L. Rev. 61 (1997); Sidney A. Shapiro \& Richard E. Levy, Judicial Incentives and Indeterminacy in Substantive Review of Administrative Decisions, 44 DuKE L.J. 1051 (1995); Sidney A. Shapiro, Substantive Reform, Judicial Review, and Agency Resources: OSHA as a Case Study, 49 Admin. L. Rev. 645 (1997); Peter L. Strauss, From Expertise to Politics: The Transformation of American Rulemaking, 31 WAKE Forest L. Rev. 745 (1996); Mark Seidenfield, Demystifying Deossification: Rethinking Recent Proposals to Modify Judicial Review of Notice and Comment Rulemaking, 75 TEx. L. Rev. 483 (1997); Mark Seidenfeld, Hard Look Review in a World of TechnoBureaucratic Decision-Making: A Reply to Professor McGarity, 75 Tex. L. Rev. 559 (1997).

142. Treaty Establishing the European Community, supra note 15, art. 230.

143. Schwarze, supra note 35 , at 158. 
underlines that the European courts do not place too high a demand on the evidence of an essential infringement, which is excluded, for example, when the infringement does not have influence on the final decision (that is the case when European authorities have no discretion to adopt an act).

Regarding national laws, Germany's administrative procedure act, passed in 1976 and modified in the 1990s, now establishes that procedural defects do not invalidate the final decision. ${ }^{144}$ There is just one exception: that it is clear that the defect has had a direct impact on the substance of the final decision. In the case of Spanish regulation, procedural defects will provoke the nullity of the final decision only if: (a) there is no procedure at all; (b) the defect denies a proper defense; and (c) the final decision cannot achieve the legally programmed goal because of the procedural default. ${ }^{145}$

There is a lack of EU regulation regarding the effects of procedural failures. Neither the Charter nor the Code says anything about this question. Article 41 of the Charter does not mention anything on the thorny subject of the transcendence of procedural defects, which gives rise to a breach of the duty of good administration, and raises the possible existence of irrelevant procedural defects for the final decision, the so-called "harmless error principle."

It may be said that judicial review is a very sensitive tool that has to be used firmly and carefully. It can promote good administration, but it can also introduce undue interference, delay, and public expenditure.

To conclude, I would like to refer to what I consider to be the first case in which the CFI has found the right to good administration as controlling. In Max.Mobil Telekommunikation Service $G m b H,{ }^{146}$ the applicant had to pay the same amount in fees as a partially state-owned operator. The private company claimed a breach of free competition. The judgment dealt with two questions. First, does the Commission have unlimited discretion to decide if undertaking a procedure under Articles 86 and 90 of the Treaty, and second, was the Treaty breached?

The first question was answered in the negative:

Since the present action is directed against a measure rejecting a complaint, it must be emphasised at the outset that the diligent and impartial treatment of a complaint is associated with the right

144. Art. 46 of the German Administrative Procedure Act (1976) (modified in the 1990s).

145. Spanish Common Administrative Procedure Act (1992).

146. Case T-54/99, Max.mobil Telekommunikation Service GmbH v. Commission, 4 C.M.L.R. 32 (2002) (citation omitted). 
to sound administration which is one of the general principles that are observed in a State governed by the rule of law and are common to the constitutional traditions of the Member States. Article 41(1) of the Charter of Fundamental Rights of the European Union proclaimed at Nice on 7 December 2000 confirms that "[e]very person has the right to have his or her affairs handled impartially, fairly and within a reasonable time by the institutions and bodies of the Union." ${ }^{147}$

Therefore, the right to good administration imposes a duty, providing a judicial action to individuals.

The Commission has the obligation of undertaking a diligent and impartial examination of complaints submitted. It is an obligation to act in a proper way, not an obligation to achieve any particular outcome. While emphasizing that the Commission has no obligation to take action against Member States, case law does not imply that the Commission is not under an obligation to undertake a diligent and impartial examination of complaints. The breach of such a duty gives a cause of action to applicants to defend their right to good administration. Standing is thus acieved by such a right.

With regard to the breach, the Court underlined that it cannot reach the merits of the decision. It only can decide whether: the statement of reasons is prima facie consistent, and gives due consideration of the relevant aspects of the case; facts are materially accurate; and the prima facie assessment of those facts is not vitiated by any manifest error.

In this particular case, the Court dismissed all the allegations, saying that there was no mistake of fact:

It can be inferred from those two grounds that the Commission identified the central issue of the complaint, giving the impression that it took account of the relevant issues. Moreover, it is clear that the contested measure is based on facts whose materiality is not contested in so far as the parties agree that the fees paid by the applicant and by Mobilkom are of the same amount. Finally, it must be noted that the Commission, without committing any manifest mistake in their assessment, concluded, on the basis of a prima

147. Id. 
facie examination of the file, that the imposition on Mobilkom of a fee identical to that paid by the applicant is not in itself sufficient to show that Mobilkom was induced to abuse its dominant position. That conclusion is consistent with the Commission's previous practice and, more particularly, with the GSM Italy and GSM Spain Decisions, in which the Commission concluded that the historical operator concerned had been encouraged to abuse its dominant position as a result of the payment by the new entrants to the market of a fee higher than that paid by the historical operator. ${ }^{148}$

This conclusion is debatable. It assumes that equal fees mean free competition, and assumes that the Commission had enough information to decide, which is at least, dubious.

The court decides that the reasons finally given by the Commission, plus the previous meetings, are enough to consider that the private company had proper opportunities for defense. It is important to remember that Article 253 of the EC Treaty demands a justification for European decisions. This article has to be read in light of Article 41.2 of the Charter of Fundamental Rights. As we have seen, the duty of giving reasons is not established just for defensive purposes. From that perspective, was the explanation given complete enough to guarantee a proper use of powers? That is the basic question.

In conclusion, the Court states formally that a right to good administration exists, but perhaps fails to establish a proper standard of due diligence to develop it.

\section{And Finally, Some Ideas Concerning Rulemaking Procedures}

Although this article has dealt with adjudicative decisions, some of its ideas could probably be applied to rulemaking procedures. ${ }^{149}$

To finish the study, I would like to refer to an interesting article written by Professor Shapiro. ${ }^{150}$ His article outlines a rather critical point of view about

148. Id. para. 75 .

149. See, e.g., Theodora Ziamou, New Process Rights for Citizens? The American Tradition and the German Legal Perspective in Procedural Review of Rulemaking, Pub. L., Winter 1999, at 726; Theodora Ziamou, Rulemaking, Participation and the Limits of Public Law in the USA and Europe (2001).

150. See Martin Shapiro, Equality and Diversity, 11 Eur. Rev. Pub. L. 400 (1999). Shapiro later develops his thoughts in Trans-Atlantic: Harlow Revisited, in Law and Administration in Europe: Essays in Honour of Carol Harlow 226 (Paul Craig \& Richard Rawlings eds., 2003). 
European procedures. According to Shapiro, regulation has shifted in scope, moving from the national to the European arena, and in style, from closed, negotiated procedures to lobbying.

The complexity of the current world has generated the current European model of regulation. This model should be a technocratic, efficient one. Technical specialists use technical means, such as cost-benefit analyses to get efficient, neutral regulations. There is a technocratic legitimacy, and an unequal distribution of costs, theoretically compensated by policies of distribution.

Thus, in Shapiro's view, European regulation is apparently apolitical, but it is a combination of technical and political aspects, within an atmosphere of opacity. Shapiro advocates a different model: the participatory model of regulation. This entails open procedures to participation. Participants should be allowed to speak and be heard.

But this model has its own problems. Equality in participation could be formal, not real. Powerful groups have more opportunities to combat this problem in the United States, where there are policies of affirmative action helping some weaker groups to participate. Further, participation could slow down procedures, making them more rigid and expensive. On the other hand, negative aspects of the proposed model must be balanced with the positive, among them the reduction of unexpected consequences.

What is Shapiro's forecast about the future model of regulation in Europe? He believes that firms seek uniformity in regulation in all European countries, and this requires more uniform procedures. The powerful groups-the elitewant to ensure that they will be included in the decision-making process and will press for more formalized legal procedures to gain more influence. Thus they will open the door to less powerful collective interests (e.g., consumers, environmentalists, and workers), enhancing participation and transparency. This future model of European regulation will put on the table the important role of judicial review of procedure. And here the U.S. model could be useful as a mirror image in order to develop its good aspects and to avoid its mistakes in Europe. ${ }^{151}$

Although I do not intend to develop Shapiro's arguments any further at this time, I think that these could help to open new perspectives of discussion in the European sphere.

151. Regarding the difference between the European situation and the American situation, see Antonio La Spina \& Giandomenico Majone, Lo Stato regolatore 187 (2000) (promoting the approval of a European Administrative Procedure Act in order to gain transparency and improve judicial review of Community regulations). 